\title{
Exploring Critical Discourse Analysis's Renowned Studies: Seeking for Aims and Approaches
}

\author{
Nurul Fathia Salma \\ SMA Negeri 3 Pekanbaru, Indonesia \\ nurul_tiaa@yahoo.com
}

\author{
ARTICLE HISTORY \\ Received : 2019-06-08 \\ Revised : 2019-06-12 \\ Accepted : 2019-06-23

\section{KEYWORDS} \\ Critical Discourse Analysis (CDA) \\ Approaches \\ Aims \\ Framework
}

\begin{abstract}
This paper is trying hard to linked all its resources the study conducted by renowned researchers which discuss about Introduction to Critical Discourse Analysis (CDA) where includes the definitions, the manner to do Critical Discourse analysis guided by the established framework. Based on the theories of Michel Foucault, "discourse analysis is focusing on power of relationships in society as expressed by means of language and practices" this study puts its stand of viewpoint. Besides, there are several renowned studies to help understand the principle e.g., aims and approaches of CDA. This study believed and stick to the Foucauldian discourse analysis look at how the figures used language to propose their power dominance, and request obedience and honor from those subordinate to them which they are five steps are recommended based on the identification of rules in using "Foucauldian discourse analysis". However this study also still a high admiration to others scholars aims and approaches used e.g. Van dijk, Wodak and Faiclough.
\end{abstract}

\section{Introduction}

On the article of Frohmann (1994) "Discourse analysis is a way of approaching and thinking about a problem provide a tangible answer to problems based on scientific research, and enables us to understand the conditions behind a specific problem and make us realize that the essence of that problem, and its resolution". Indeed, "DA provides a basic methodology to describes and analyze how the structure and content of the text encodes ideas and the relation among the ideas itself that are present in the text, systematically". (Hamuddin, 2012).

Therefore, in this article, the author will discuss about interdisciplinary approach to the study of discourse that views language as a form of social application called Critical discourse analysis (CDA). According to Van Dijk (2004) "Critical Discourse analysis is a type of discourse analysis research that primarily studies the way social power abuse, dominance, and inequality are enacted, reproduced, and resisted by text and talk in social and political contexts".

Moreover, this study suggested Discourse Analysis, more particularly written Discourse Analysis since we are dealing with newspaper, in collaboration with CDA, to form a worthy framework and methodology could help analyses the news from the critical point of view. The idea of forming Discourse Analysis and Critical Discourse Analysis in analyzing news among others discipline. Ruth Wodak in her terminology said (Kendall: 2007) "this paper might call as "integrated interdisciplinary": integrating approaches for an object under investigation in innovative ways.

This paper may find a more or less critical perspective in such diverse areas as pragmatics, conversation analysis, narrative analysis, rhetoric, stylistics, sociolinguistics, ethnography, or media analysis however using CDA framework shall be the right choice to works under written DA methodology."

It emerged from 'critical linguistics' be expanded on 1970s at the University of East Anglia, and the terms are not often interchangeable. The major contribution of this study is called Ruth Wodak. Besides, Norman Fairclough who the Lancaster school of linguists was the most prominent figure of the first developing of CDA.

According to Van Dijk (1995), CDA is a special approach in discourse analysis, components, and consequences of Ulinnuha et al., Therefore, this paper will describe the definitions of Critical Discourse Analysis according to the experts especially Teun A. van Dijk. Besides, the definitions and aims this study also elaborate some approach on how to implement critical discourse analysis. Thus, this study believed it's necessary to know the theoretical Frameworks in CDA as well. 


\subsection{Definitions and Characteristic of CDA}

The phenomena of social are linguistics, in other words, the language activity that take place on social contexts and it is a part of the processes and practices. The first time in studying CDA, we have to know what Discourse Analysis is. According to, in semantics and discourse analysis, the meaning of discourse is a generalization of conceptual in conversation within each context of communication". Meanwhile, analysis is the process to solve a complex topic into smaller parts in order to acquire a better comprehension of it. Thus, an interdisciplinary approach to the study of discourse that regarded languages as a form of social practice called Critical Discourse Analysis (CDA). It has become the general etiquette for a particular approach to the study of talk and text, appearing from Critical Semiotic, Critical Linguistic, and commonly from a socio-politically aware and the manner of opposition in enquire language, discourse and also communication. In studying a language and discourse studies, surely there are many fields, approaches, sub disciplines, and others. As well as in the case of studying CDA, it is not easy to limit the specific principles, practices, goals, theories or methods of CDA. However, in studying CDA, it is usually characterized by the following features:

CDA is part of critical studies about humanities and social science for examples; in sociology, psychology, mass communication research, law literature and political science. It is usually discuss the effective about the study relevant social problems, such as those of sexism, colonialism, racism and other forms of social inequality. Much work in CDA is about the underlying ideologies that play a role in against inequality. Besides, it focuses in the relation and also interrelated between Discourse and Society, such as (Politics, culture, economic, social, etc.). When learning the role of discourse especially on society, CDA particularly focuses on (groups) relation of power resisted by social group members through talk and text.

CDA commonly focuses on the strategies of manipulation, legitimation, the manufacture of consent and other discursive ways to influence the minds (indirect actions) of people in the interest of the powerful. Besides, a school, a subdicipline, or field of discourse analysis does not characterized by CDA, however it categorize an critical approach, position or the corner of studying talk and text explicitly. It (may) pay attention to all dimension of discourse, such as grammar (phonology, syntax, and semantics), schematics organization, strategies of pragmatic, speech acts, interaction, etc. In the other hand, it also pay attention to other dimensions like semiotic (sound, music, picture, film, videos, gesture, etc.) on communicative events.
Indeed, studies in CDA try to formulate or sustain an overall perspective solidarity with dominated groups, e.g., by formulating strategic proposals for the enactment and development of counter-power and counter-ideologies in practices of challenge and resistance.

Based on the theories of Michel Foucault, discourse analysis is focusing on power of relationships in society as expressed by means of language and practices. Besides focusing on the significance of a given discourse, the differentiator characteristic in this approach is the emphasis on the power of relationships. These are expressed through behavior and language, the relationship between language and power. So, This analysis try to comprehend how individuals envisage the world, and learn categorizations, politics, ideology, social and also personal and institutional relationships. Studies used the Foucauldian discourse analysis can look at how the figures used language to propose their power dominance, and request obedience and honor from those subordinate to them. In a specific example, a study may look at the language used by teachers towards students, or military officers towards conscripts. This approach could also be used to study how language is used as a form of reciprocal to those in power.

\subsection{Requirements for Conducting CDA}

Critical discourse Analysis needs to fulfill a number of requirements in order to effectively actualize its aims: First, Critical Discourse Analysis has to be "better" than other research in order to be accepted. Second, it focuses essentially on political issues and social problems, rather than on current fashions and paradigms. In other requirements i.e. empirically adequate the critical analysis of social problems is usually multidisciplinary. Fourth, rather than purely describe discourse structures, Critical Discourse Analysis make efforts to account them in terms of characteristics of social interaction and especially social structure.

More particularly, Critical Discourse Analysis concentrate on the ways discourse structures figure, ensure, legitimate, reproduce, reasonable, or challenge the links of dominance and power in society. Moreover, Fairclough and Wodak (1997) sum up the main concepts of Critical Discourse Analysis as follows: First, Critical Discourse Analysis discuss socials and politics problems. Second, power relations are erratic (discursive). Third discourse is a form of society and culture. Fourth, discourse carry out ideological works. Fifth, discourse is historical, sixth, the link between society and text are mediated. Seventh, Critical Discourse analysis is interpretative and explanatory. The last, Critical Discourse Analysis is a form of social proceeding or action. 


\section{Method}

\subsection{The Manners to Do CDA}

The current news either online or printed news can be utilize as a great source of learning analyzing language in use and it also present interesting material to regard. To bring current issues and hot news taken from media such as news in social media, magazine or newspaper need more than just interpretive or catching specific information by way of reading, it needs a second approach to espouse Critical Discourse Analysis.

Hence we need to bring the students to more conscious and critical to the news posted in the media (papers or media social), hence we need Critical Discourse Analysis (CDA) framework. Thereto, it can help the students in ELT (English Language Teaching) classroom grow more obverse in seeing the news and through the news. Thus, the students can learn to see news at least from 3 different level in Discourse Analysis class by using Critical Discourse Analysis based on Fairclough's three dimensional frameworks, among others: text, discursive practice and social practice.

Students usually will want to know "how to do CDA". Firstly, formulate the proposals for successful strategies of research. Second, we need to identify which structure and strategies of talk and text to attend in order to discover patterns of manipulation "in" texts theoretically and descriptively. Vice versa, focusing on major social, political problems and issues such as sexism and racism, we need to detail how such forms of inequality are expressed, enacted, legitimated, and reproduced by text and talk. Kendall and Wickham outline five steps in using "Foucauldian discourse analysis". The first step is a simple admission that discourse is a set of statements that are organized in a systematic way. The subsequent four steps are based on the identification of rules on: How those statements are created; what can be said (written) and what cannot; how the spaces in which new statements can be raised are created; and making practices material and discursive at the same time.

In brief, CDA needs good theories of the role of discourse in the ratification and facsimile of resistance and social dominance. More than theories which only demand descriptive or explanatory sufficiency, however, CDA which is successful must be effective: in the conclusions, recommendations and the other interference must work. These are fairly difficult criteria. In that situation, CDA is not only a scientific practice, but also a scientific research programs. Orientation questions for frame application, includes: Is this a typical text of its type? , who produced this?; who will read it?; will everyone understand this text in the same way?; why was it produced?; in what other ways could it have been written?; what is missing from this text?; how does this text reflect the wider society?; What could we do about this text if we disagree with it?

\section{Result and Discussion}

\subsection{Theoretical Frameworks}

In the aims of Critical Discourse analysis mentioned atop, there are many types of Critical Discourse Analysis, and these may be analytically and theoretically quite diverse. Critical analysis of news reports in the press or of lessons and teaching at school are very different from Critical analysis of conversation. Therefore, the typical vocabulary of many scholars in Critical Discourse Analysis will show such ideas as "power", "dominance", "ideology", "hegemony", "gender", "class", "discrimination", "race", "interests", "institutions", "reproduction", "social order", and "social structure". In this part, the author will focus in a number of basic concepts themselves and devise a theoretical framework that critically relate with discourse, society and cognition.

\subsubsection{Micro vs. Macro}

Discourse, language use, communication and verbal interaction belong to the micro level of the social array. Power, inequality and dominance between social groups are in particular terms that belong to a macro level of analysis. It means that Critical Discourse analysis should theoretically bridge the well-known "gap" between micro and macro approaches, which is of course a difference that is a sociological construct in its own right (Alexander et al. 1987; Knorr-Cetina and Cicourel 1981). There are certain ways to analyses these levels to arrive at a unified critical analysis as follows:

a) Members-groups: Language users participate in discourse as a member of (several) social groups, organizations, or institutions; and vice versa, groups may act "by" their members.

b) Actions-process: Social acts of individual actors are thus element of social processes and group actions, such as news making, legislation or the propagation of racism.

c) Context-social structure: Situations of discursive interaction are similarly part or principle of social structure; for example, a press conference may be a particular practice of organizations and media institutions. That is, "local" and more "global" contexts are tightly related, and both utilize constraints on discourse.

\subsubsection{Power as Control}

A central idea in most critical work on discourse is that of power, and more particularly the institutions or social power of groups. Summarizing a complex social and philosophical analysis, we will define social power in the terms of control. 
Finally, this means that those groups who control most dominant discourse also have more opportunity to control the ideas (minds) and actions of others. Simplifying these very complicated relationships, the author can divorce the issue of discursive power into three basic questions for Critical Discourse Analysis research: How can groups with more power control the public discourse? ; How does such discourse control the mind and action of groups which is less powerful? And; what are the social effect of such control, such as social dissimilarity?

\subsection{Power and Access}

Power which divided into two kinds are social power and power abuse. Where social power is (approximately) defined as a form of control of one group to another, while power abuse further implies that the control is in the interest of the dominant group, this means that dominant social group members may exercise such control over talk and text.

Access is defined in terms of their (powerful) social or institutional position or function and vice versa. And Discourse: Patterns of discourse control and access are indeed closely associated with social power. That is, discursively implemented dominance involves preferential access to text and context taken as a basis or resource of power, comparable to such social resources as wealth, income, a good job, position, status, knowledge and education.

Thus, whereas ordinary people only have active access to, and control over such discourse genres as everyday conversations with family members, friends or colleagues, and more passive access to institutional For examples: Politicians have control over, e.g. governmental and parliamentary discourse, and preferential access to the mass media; Scholars control academic discourse, such as lessons, textbooks, courses and scholarly publications. ;Journalists have control over mass media discourse and preferential access to a host of other forms of official talk and text, such as press conferences, press releases, reports, and soon.

\section{Conclusion}

Based on the description above, the authors conclude: Critical Discourse Analysis is a particular approach in discourse analysis which focuses on the result or consequences of power abuse by dominant groups and institutions. CDA opposes the abuse of power that is usually done by high officials and institutions dominant by finding and criticizing mistakes. Critical Discourse Analysis aimed at yielding 'emancipation and enlightenment'. Critical Discourse Analysis search not only to explain and describe, but also to eradicate a particular kind of fantasy. Even with differing construct of ideology, Critical Theory search to create awareness in agents of their own needs and concern. (Faiclough and
Wodak: 2008) Besides, in conducting discourse analysis we need to identify which structure and strategies of talk and text to attend in order to discover patterns of manipulation "in" texts theoretically and descriptively. In addition, the CDA aims as a research program.

Further, CDA is a type of discourse analytical research that primarily studies the way social power abuse, dominance, and inequality are enacted, reproduced, and resisted by text and talk in the social and political context. It has a concern with representations of societal issues, hidden agendas, texts that impact on people's lives it claims therefore to take an ethical stance in addressing power imbalances, inequities, and social justice agenda to spur readers into resistant and corrective social action.

\section{Acknowledgement}

This research was supported/partially supported by Dept. of English Education, FKIP Universitas Lancang Kuning. We thank our colleagues who provided insight and expertise that greatly assisted the research, although they may not agree with all of the interpretations/conclusions of this paper.

\section{References}

Alvesson, M., \& Kärreman, D. (2011). Decolonializing discourse: Critical reflections on organizational discourse analysis. Human relations, 64(9), 1121-1146.

Boden, D., \& Zimmerman, D. H. (Eds.). (1991). Talk and social structure: Studies in ethnomethodology and conversation analysis. Univ of California Press.

Breeze, R. (2011). Critical discourse analysis and its critics. Pragmatics, 21(4), 493-525.

Bull, T., \& Swan, T. (Eds.). (1992). Language, sex, and society. Mouton de Gruyter.

Chilton, P. A. (1985). Language and the nuclear arms debate: Nukespeak today. Pinter Pub Ltd.

Drew, P., \& Heritage, J. (1992). Talk at work: Interaction in institutional settings. Cambridge Univ Pr.

Duanprakhon, P. (2012). Critical discourse analysis of news headlines: a case of youth crime in Thailand. School of Language and Communication National Institute of Development Administration.

Fairbanks, C. M., Duffy, G. G., Faircloth, B. S., He, Y., Levin, B., Rohr, J., \& Stein, C. (2010). Beyond knowledge: Exploring why some teachers are more thoughtfully adaptive than others. Journal of Teacher Education, 61(1-2), 161-171. 
Fairclough, I., \& Fairclough, N. (2013). Political discourse analysis: A method for advanced students. Routledge.

Fairclough, N. (1989). Language and Power\| Longman.

Fairclough, N. (2013). Critical discourse analysis and critical policy studies. Critical policy studies, 7(2), 177-197.

Fairclough, N. (2013). Critical discourse analysis. R. Wodak (Ed.). London: Sage.

Fisher, S., \& Todd, A. D. (Eds.). (1986). Discourse and institutional authority: Medicine, education, and law (Vol. 19). Praeger Pub Text.

Foucault, M. (1980). Power/knowledge: Selected interviews and other writings, 1972-1977. Pantheon.

Fowler, R. (1991). Discourse and Ideology in the Press. Routledge.

Gee, J. P., \& Handford, M. (Eds.). (2013). The Routledge handbook of discourse analysis. Routledge.

Geis, M. L. (2012). The language of politics. Springer Science \& Business Media..

Hamuddin, B. (2012). A comparative study of politeness strategies in economic journals (Doctoral dissertation, University of Malaya).

Hamuddin, B. (2015). DISCOURSE ON MEDIA: Bringing Hot News into ELT's Classroom Discussion. Proceedings of ISELT FBS Universitas Negeri Padang, 3, 87-95.

Hamuddin, B., \& Noor, F. N. M. (2015, August). A Closer Look on Politeness Strategies in Malaysian Economic Journal. In 2nd INTERNATIONAL SEMINAR ON LINGUISTICS (p. 52).

Hart, C. (2010). Critical discourse analysis and cognitive science: New perspectives on immigration discourse. Springer.

Hodge, R., \& Kress, G. (1988). Social Semiotics. London: Polity Press.

Hodge, R., \& Kress, G. (1993). Language as ideology (Vol. 2). London: Routledge.

Johnson, D. C. (2011). Critical discourse analysis and the ethnography of language policy. Critical discourse studies, 8(4), 267-279.

Johnstone, B. (2018). Discourse analysis. John Wiley \& Sons.

Kedar, L. (1987). Power through discourse. Ablex Publishing Corporation.
KhosraviNik, M. (2010). The representation of refugees, asylum seekers and immigrants in British newspapers: A critical discourse analysis. Journal of language and Politics, 9(1), $1-28$.

Kramarae, C., Schulz, M., \& O'Barr, W. M. (1984). Language and power. Sage Publications, Inc.

Kress, G. (2013). Representational resources and the production of subjectivity: Questions for the theoretical development of Critical Discourse Analysis in a multicultural society: Gunther Kre. In Texts and practices (pp. 24-40). Routledge.

Krzyżanowski, M. (2011). Ethnography and critical discourse analysis: towards a problem-oriented research dialogue. Critical Discourse Studies, 8(4), 231-238.

Machin, D. (2013). What is multimodal critical discourse studies?. Critical discourse studies, 10(4), 347-355.

Mauranen, A. (2012). Exploring ELF: Academic English shaped by non-native speakers. Cambridge University Press.

Musolff, A. (2012). The study of metaphor as part of critical discourse analysis. Critical discourse studies, 9(3), 301-310.

Paltridge, B. (2012). Discourse analysis: An introduction. Bloomsbury Publishing.

Poole, B. (2010). Commitment and criticality: Fairclough's critical discourse analysis evaluated. International Journal of Applied Linguistics, 20(2), 137-155.

Rahimi, F., \& Riasati, M. J. (2011). Critical discourse analysis: Scrutinizing ideologically-driven discourses. International Journal of Humanities and Social Science, 1(16), 107-112.

Rambe, P. (2012). Critical discourse analysis of collaborative engagement in Facebook postings. Australasian Journal of Educational Technology, 28(2).

Tannen, D., Hamilton, H. E., \& Schiffrin, D. (Eds.). (2015). The handbook of discourse analysis (Vol. 1). Malden^ eMA MA: Wiley Blackwell.

Teun A. Van Dijk (1988). Orwellian Language and the Media. London: Pluto Press

Teun A. Van Dijk (1992). Discourse and Social Change. Oxford: Polity Press.

Teun A. Van Dijk (eds.) (1988). Gender and Discourse: The Power of Talk. Norwood, NJ: Ablex Publishing Company. 
Teun A. Van Dijk Bob Hodg, Gunther Kress, and T. Trew. (1979). Language and Control. London: Routledge \& Kegan Paul.

Teun A. Van Dijk. (1992). Discourse and Social Change. Oxford: Polity Press.

Teun A. Van Dijk. (eds.) (1988). Gender and Discourse: The Power of Talk. Norwood, NJ: Ablex Publishing Company.

Teun A. Van Dijk. Critical Discourse Analysis

Threadgold, T. (2013). Cultural studies, critical theory and critical discourse analysis: Histories, remembering and futures.

Van Dijk, T. A. (2015). Critical discourse analysis. The handbook of discourse analysis, 466-485.

Wodak, R. (2011). Critical linguistics and critical discourse analysis. Discursive pragmatics, 50-70.

Wodak, R., \& Meyer, M. (Eds.). (2015). Methods of critical discourse studies. Sage. 